\title{
Late-entry commercial thinning effects on Pinus banksiana: growth, yield, and stand dynamics in Québec, Canada
}

\author{
Martin-Michel Gauthier ${ }^{1,2} \cdot$ Stéphane Tremblay $^{1}$
}

Received: 9 February 2018/ Accepted: 26 March 2018/Published online: 31 July 2018

(C) The Author(s) 2018

\begin{abstract}
We studied late-entry commercial thinning effects on growth, yield, and regeneration in a 48-year-old jack pine (Pinus banksiana Lamb.) stand. Applied thinning intensities were 27,32 , and $47 \%$ of merchantable basal area (BA) excluding skidding trails. After 15 years, mean diameter at breast height of surviving trees in the $47 \%$ BA removal increased by $4.9 \mathrm{~cm}(25 \%)$ compared to the unthinned control. The 47\% BA removal also increased gross merchantable volume (GMV) tree ${ }^{-1}$ by $46 \%$ compared to the control. The $27 \%$ BA removal had twice as much GMV ha ${ }^{-1}$ compared to the $47 \%$ BA removal after 15 years. Moreover, cumulative $\mathrm{GMV}$ ha $^{-1}$ was much higher in the $27 \%$ BA removal than in the unthinned control. The highest thinning intensity produced larger trees on average, while the lowest thinning intensity maximized volume production per hectare. Maintenance of acceptable growing stock throughout the 15 -year period in the $27 \%$ BA removal could provide other ecosystem functions such as biodiversity enhancement or wildlife habitat by delaying senescence. Regeneration data showed
\end{abstract}

Project funding: The work was supported by the grant from Forest Research Branch of the Québec Ministry of Forests, Parks, and Wildlife (No. 142332012).

The online version is available at http://www.springerlink.com

Corresponding editor: Tao $\mathrm{Xu}$.

Martin-Michel Gauthier

martin-michel.gauthier@canada.ca

1 Ministère des Forêts, de la Faune et des Parcs du Québec, 2700 rue Einstein, Québec, QC G1P 3W8, Canada

2 Natural Resources Canada, Canadian Forest Service, 580 Booth St, Ottawa, ON K1A 0E4, Canada that a shift in species composition occurred in the understory. After 15 years, the understory was dominated by black spruce (Picea mariana (Mill.) B.S.P.), white birch (Betula papyrifera Marsh.), and trembling aspen (Populus tremuloides Michx.). If regenerating jack pine is an objective after final overstory removal, additional efforts will be needed to re-establish this species.

Keywords Jack pine $\cdot$ Commercial thinning $\cdot$ Stand yield . Succession - Delayed senescence $\cdot$ Tree regeneration

\section{Introduction}

Jack pine (Pinus banksiana Lamb.) is a short-lived, shadeintolerant, pioneer species (Lichter 1998) that regenerates readily after fire from canopy-stored seed banks (Greene et al. 1999; Arseneault and Sirois 2004). This species forms an early successional forest type (Bergeron and Dubuc 1989; Chun and Choi 2012) common in North America. Jack pine is often found in pure stands, but it can also be associated with other conifers such as shade-tolerant black spruce (Picea mariana (Mill.) B.S.P.) and balsam fir (Abies balsamea (L.) Mill.), as well as hardwood species such as shade-intolerant trembling aspen (Populus tremuloides Michx.) and white birch (Betula papyrifera Marsh.).

Jack pine is an important commercial timber species. Its wood is used for a variety of products including panelling, furniture, and industrial lumber. In the last decade, concerns over future volume supply spurred interest in tending silvicultural treatments such as pre-commercial thinning (PCT) and commercial thinning (CT; see Table 1 for a list of all abbreviations). Both PCT and CT lower stand density to increase growth of residual trees, but CT is carried out at a later stage in stand development when trees are 
Table 1 List of abbreviations used in this study

\begin{tabular}{|c|c|c|}
\hline Abbreviation & Definition & Measurement units \\
\hline $\mathrm{BA}$ & Merchantable basal area per hectare & $\mathrm{m}^{2} \mathrm{ha}^{-1}$ \\
\hline $\mathrm{C}$ & Fixed effect of the covariate & \\
\hline $\mathrm{CT}$ & Commercial thinning & \\
\hline CT27 & CT with $27 \%$ mean BA removal & \\
\hline CT32 & CT with $32 \%$ mean BA removal & \\
\hline CT47 & CT with $47 \%$ mean BA removal & \\
\hline DBH & Diameter at breast height & $\mathrm{cm}$ \\
\hline ddf & Denominator degrees of freedom & \\
\hline GMV tree ${ }^{-1}$ & Mean gross merchantable volume per tree & $\mathrm{m}^{3}$ tree $^{-1}$ \\
\hline GMV ha $^{-1}$ & Mean GMV per hectare & $\mathrm{m}^{3} \mathrm{ha}^{-1}$ \\
\hline GSV ha ${ }^{-1}$ & Mean gross sawlog volume per hectare & $\mathrm{m}^{3} \mathrm{ha}^{-1}$ \\
\hline CGMV & Cumulative GMV production per hectare & $\mathrm{m}^{3} \mathrm{ha}^{-1}$ \\
\hline ndf & Numerator degrees of freedom & \\
\hline PCT & Precommercial thinning & \\
\hline SE & Standard error of the mean & \\
\hline SI & Site index of jack pine at age 50 & $\mathrm{~m}$ \\
\hline $\mathrm{T}$ & Fixed effect of thinning & \\
\hline $\mathrm{Y}$ & Fixed effect of time (year) & \\
\hline
\end{tabular}

merchantable $(>9.0 \mathrm{~cm}$ in diameter at breast height; $\mathrm{DBH})$. CT can help generate revenue during the rotation period. Several studies have been carried out to determine the influence of PCT (Barbour et al. 1994; Tong and Zhang 2005; Tong et al. 2005; Zhang et al. 2006; Bell et al. 2011) and CT (Schneider et al. 2008; Krause et al. 2011) on the growth response and wood properties of jack pine. Both treatments were also studied to determine the potential for shifting the emphasis from maximizing volume to maximizing economic value. As such, long-term monitoring of replicated experimental designs is essential to determine the impact of thinning on tree growth and stand yield and help guide sustainable forest management practices. Such practices could also influence the maintenance of other important ecosystem functions through the development of structural heterogeneity (Drössler et al. 2014; Gauthier et al. 2015; Sullivan and Sullivan 2016) or by delaying senescence (Soucy et al. 2012).

There is currently a lack of information on regeneration dynamics after CT in managed stands because regenerating a new cohort is generally not one of the objectives of this treatment. Nevertheless, this aspect is important because jack pine is notoriously difficult to regenerate naturally without fire (Waters et al. 2004). Indeed, short-term (2 years) regeneration after clearcutting is less abundant than after fire on sandy soils (Béland et al. 2003a). Over the long-term, jack pine abundance has been shown to decrease after decades of fire suppression and logging (Friedman and Reich 2005). Thus, investigating regeneration dynamics will increase our knowledge of the regeneration of commercially thinned jack pine stands prior to final overstory removal. It will also help quantify the potential change in species composition in the understory. Indeed, establishment of shade-tolerant species such as black spruce could lead to a shift from jack pine-dominated to black spruce-dominated conifer stands.

Hence, we report on a long-term CT experiment initiated in 1997 in a mature jack pine stand and remeasured over 15 years. This time frame is long enough to include the early stages of senescence, which is uncommon in the scientific literature. Specific objectives include: (1) determining the influence of three CT intensities [27-47\% basal area (BA) removal excluding skidding trails] on growth and yield; and, (2) investigating natural regeneration dynamics after thinning in terms of density and stocking. We hypothesize that (1) tree growth will increase with increasing thinning intensity, but not stand yield; and, (2) shade-intolerant tree species such as jack pine will have difficulty regenerating after $\mathrm{CT}$ regardless of thinning intensity.

\section{Materials and methods}

\section{Study site}

The study site is located in the Saguenay-Lac-Saint-Jean region of Québec, Canada $\left(48^{\circ} 49^{\prime} \mathrm{N}, 72^{\circ} 38^{\prime} \mathrm{W}\right)$, in the Balsam Fir-Yellow Birch [A. balsamea (L.) Mill.-Betula alleghaniensis Britt.] bioclimatic subdomain of the northern temperate ecological zone. Mean annual temperature (1981-2010) was $1.3{ }^{\circ} \mathrm{C}$, mean annual precipitation 
$804 \mathrm{~mm}$, and growing season length is 140 days. Elevation is 185 m.a.s.l. The site is located at the bottom of a gentle slope on a well-drained sandy soil created from fluvioglacial delta deposits. The stand was 48-years-old on average (age at $1 \mathrm{~m}$ in height) prior to harvest. Based on historical records, the stand likely originated from fire. Jack pine comprised $95 \%$ of the merchantable BA and trembling aspen and white birch accounted for most of the residual BA. Mean stand density was 1180 stems ha $^{-1}$, BA was $27.3 \mathrm{~m}^{2} \mathrm{ha}^{-1}$, and GMV was $220 \mathrm{~m}^{3} \mathrm{ha}^{-1}$ (Table 2). Mean live crown ratio of codominant trees was $39 \%$ and mean slenderness coefficient (height/diameter) was $92 \%$. Estimated site index (SI) was $21 \mathrm{~m}$ at age 50, which is considered very productive compared to similar sites of the region (Pothier and Savard 1998). The rotation age for maximum merchantable volume production for a jack pine stand of comparable density and site index is $\sim 37$ years (Pothier and Savard 1998).

\section{Experimental design and thinning treatments}

A randomized complete block design was established in August 1997 and consisted of four treatments: three CT intensities and an unthinned control. Each treatment was replicated three times, once in each block, for a total of 12 experimental units (hereafter referred to as replicates). Planned thinning intensities were low (25\%), intermediate $(35 \%)$, and heavy $(45 \%)$ merchantable BA removals. Actual thinning intensities were 27\% (CT27), 32\% (CT32), and $47 \%$ (CT47) excluding skidding trails. Each replicate was composed of a $2500 \mathrm{~m}^{2}$ area $(50 \times 50 \mathrm{~m})$ with a central $400 \mathrm{~m}^{2}$ circular plot $(11.28 \mathrm{~m}$ radius $)$ to measure merchantable trees. Thinning was carried out in each $2500 \mathrm{~m}^{2}$ plot by marking merchantable trees to cut based on the following order: (1) diseased or crooked trees; (2) smaller merchantable trees; and, (3) other trees that were likely to die within the next 15 years. Jack pine was preferred over other species for being left in the stand. Thinning treatments were generally carried out from below (Fig. 1). There was some harvest in $\mathrm{DBH}$ classes greater than the mean $\mathrm{DBH}$ of $16 \mathrm{~cm}$. This could be due to removal of larger defective trees or to maximize residual spacing. Mean residual density immediately after thinning

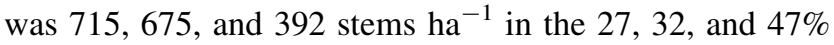
BA removals. Trees were felled manually. Winching, delimbing, and bucking were carried out using a tractormounted NIAB 5-15 processor (AS FORS MW, Saue, Estonia). The tractor-processor was located inside skidding trails that were 5-m in width and distributed outside block boundaries. Based on a jack pine stand density management diagram from Sharma and Zhang (2007) for eastern Canada, none of the replicates were considered overstocked prior to thinning.
Table 2 Preharvest and immediate postharvest characteristics of commercial thinning treatments prior to thinning

\begin{tabular}{|c|c|c|c|c|c|}
\hline \multirow{2}{*}{$\begin{array}{l}\text { Thinning } \\
\text { Treatment }\end{array}$} & \multirow[t]{2}{*}{ Characteristic } & \multicolumn{2}{|c|}{ Pre harvest } & \multicolumn{2}{|c|}{ Post harvest } \\
\hline & & Mean & SE & Mean & SE \\
\hline \multirow[t]{9}{*}{ СТ27 } & Age (year) & - & - & 50 & 5 \\
\hline & SI (m) & - & - & 21 & 0.4 \\
\hline & $\mathrm{DBH}(\mathrm{cm})$ & 17.2 & 0.3 & 19.7 & 1.5 \\
\hline & Height (m) & - & - & 19.7 & 1.0 \\
\hline & Density (trees $\mathrm{ha}^{-1}$ ) & 1233 & 136 & 717 & 96 \\
\hline & $\mathrm{BA}\left(\mathrm{m}^{2} \mathrm{ha}^{-1}\right)$ & 30.5 & 3.1 & 22.3 & 1.8 \\
\hline & $\operatorname{GMV}\left(\mathrm{m}^{3} \mathrm{ha}^{-1}\right)$ & 256 & 40 & 184 & 24 \\
\hline & Slenderness $(\%)$ & - & - & 90 & 5 \\
\hline & Live crown ratio $(\%)$ & - & - & 44 & 4 \\
\hline \multirow[t]{9}{*}{ СТ32 } & Age (year) & - & - & 48 & 0 \\
\hline & SI (m) & - & - & 21 & 0.1 \\
\hline & $\mathrm{DBH}(\mathrm{cm})$ & 16.4 & 0.3 & 18.2 & 0.5 \\
\hline & Height (m) & - & - & 19.4 & 0.1 \\
\hline & Density (trees $\mathrm{ha}^{-1}$ ) & 1208 & 137 & 675 & 80 \\
\hline & BA $\left(\mathrm{m}^{2} \mathrm{ha}^{-1}\right)$ & 26.6 & 2.1 & 18.1 & 1.4 \\
\hline & $\operatorname{GMV}\left(\mathrm{m}^{3} \mathrm{ha}^{-1}\right)$ & 214 & 21 & 142 & 13 \\
\hline & Slenderness $(\%)$ & - & - & 93 & 3 \\
\hline & Live crown ratio $(\%)$ & - & - & 36 & 5 \\
\hline \multirow[t]{9}{*}{ CT47 } & Age (year) & - & - & 48 & 3 \\
\hline & SI (m) & - & - & 21 & 0.7 \\
\hline & $\mathrm{DBH}(\mathrm{cm})$ & 17.0 & 0.2 & 20.6 & 0.7 \\
\hline & Height (m) & - & - & 19.5 & 0.1 \\
\hline & Density (trees $\mathrm{ha}^{-1}$ ) & 1050 & 104 & 392 & 36 \\
\hline & BA $\left(\mathrm{m}^{2} \mathrm{ha}^{-1}\right)$ & 26.1 & 2.0 & 13.6 & 0.6 \\
\hline & $\operatorname{GMV}\left(\mathrm{m}^{3} \mathrm{ha}^{-1}\right)$ & 218 & 24 & 111 & 6 \\
\hline & Slenderness $(\%)$ & - & - & 88 & 4 \\
\hline & Live crown ratio $(\%)$ & - & - & 44 & 2 \\
\hline \multirow[t]{9}{*}{ Control } & Age (year) & - & - & 47 & 1 \\
\hline & SI (m) & - & - & 21 & 0.4 \\
\hline & $\mathrm{DBH}(\mathrm{cm})$ & 16.0 & 0.8 & 15.9 & 0.8 \\
\hline & Height (m) & - & - & 19.2 & 0.2 \\
\hline & Density (trees $\mathrm{ha}^{-1}$ ) & 1225 & 115 & 1200 & 123 \\
\hline & $\mathrm{BA}\left(\mathrm{m}^{2} \mathrm{ha}^{-1}\right)$ & 25.9 & 0.4 & 25.3 & 0.2 \\
\hline & $\operatorname{GMV}\left(\mathrm{m}^{3} \mathrm{ha}^{-1}\right)$ & 195 & 9 & 189 & 9 \\
\hline & Slenderness $(\%)$ & - & - & 95 & 3 \\
\hline & Live crown ratio $(\%)$ & - & - & 32 & 2 \\
\hline
\end{tabular}

Abbreviations are defined in Table 1. Total height, live crown ratio, and slenderness coefficient were measured on five codominant trees per replicate

\section{Growth and yield}

A preharvest merchantable tree inventory was carried out in the $400 \mathrm{~m}^{2}$ plots by tallying trees based on species and DBH class $(2 \mathrm{~cm})$. Postharvest measurements were carried 
Fig. 1 Preharvest and postharvest diameter distributions by 2 -cm diameter classes of the four intensities of commercial thinning: $0,27,32$, and $47 \%$ merchantable basal area removals. Distributions were based on the mean of the three replicates per treatment and were smoothed for presentation. Abbreviations are defined in Table 1

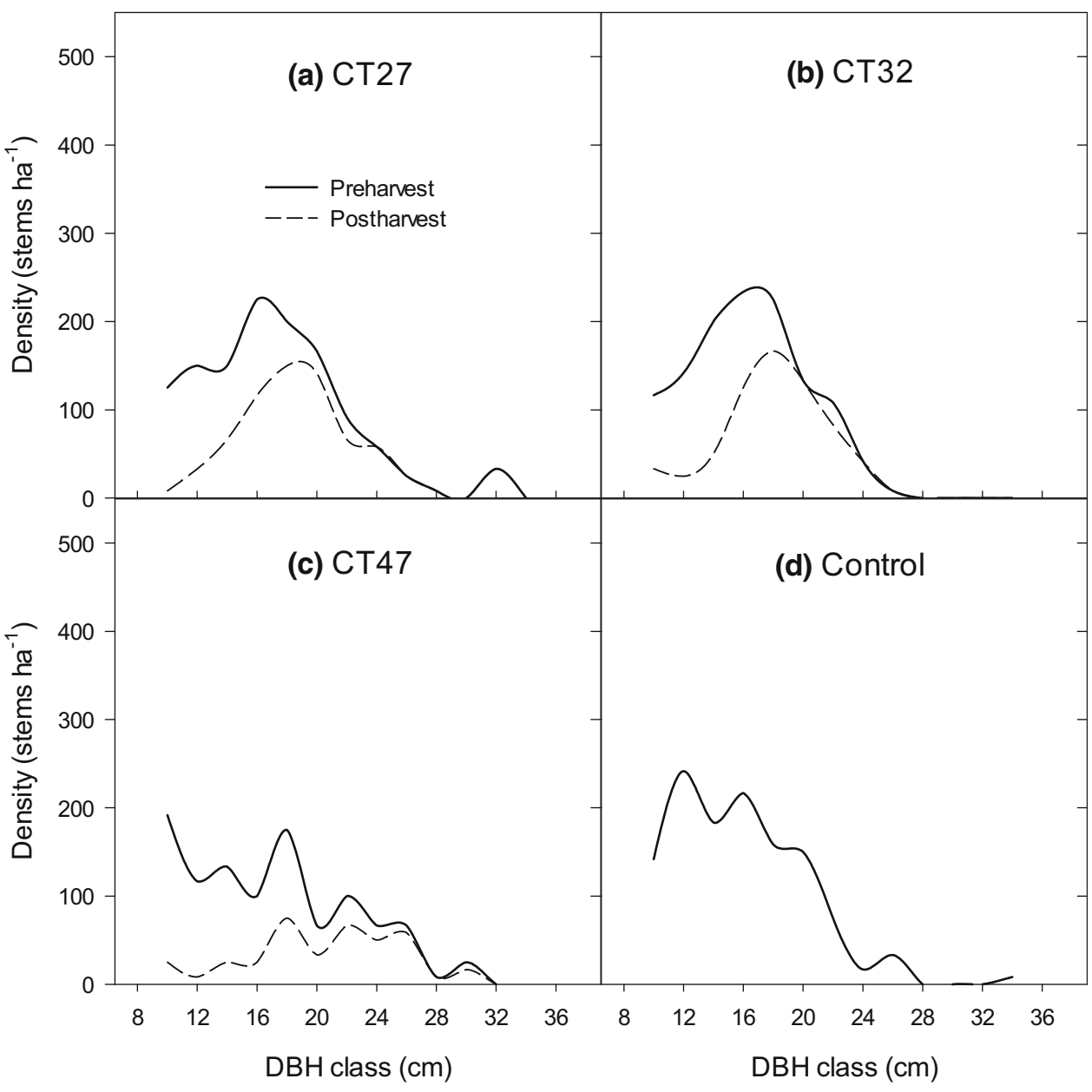

out shortly after harvest in November 1997 as well as 5, 10, and 15 years after thinning. All merchantable trees were tagged and identified by species, status (alive or dead standing, dead blowdown), and DBH (in mm). Detailed measurements were taken on five codominant trees per replicate: age at $1 \mathrm{~m}$ in height, total height, live crown ratio, and slenderness coefficient. Height measurements from these codominant trees were used to estimate height of all merchantable trees based on a height-diameter mixed-effects model from Fortin et al. (2009). The model consists of a random effect that varies by tree species to ensure a better estimation of model parameters which improves height predictions. This model was built specifically for Québec and takes into account regional features (climate, bioclimatic domain), site conditions (density, BA, quadratic mean $\mathrm{DBH}$, drainage, presence of partial cutting), and individual tree parameters (social status). Once height was predicted using the general mixed-effects model, we localized the height-diameter curve as follows. First, we calculated the difference between the observed and predicted height of each study tree. Second, we calculated a random plot effect $(x)$ for each study tree as $x=(\log (\mathrm{DBH}+1))^{2}$ (Fortin et al. 2009). Third, we carried out a repeated-measures regression (difference $=x$ ) in each of the 12 replicates to obtain the random plot parameter $\left(\beta_{1}\right)$. Thus, the height of each tree was calculated as:

Corrected height $=$ predicted height

$$
+\left(\beta_{1} \times(\log (\mathrm{DBH}+1))^{2}\right)
$$

where $\beta_{1}$ ranges from 0.2806 to 0.4769 among replicates. Height estimates were used to calculate GMV tree ${ }^{-1}$ based on Fortin et al. (2007). Thus, stand GMV was calculated as the sum of all trees in each replicate and expressed as perhectare values.

Gross sawlog volume (GSV) was calculated based on a minimum DBH of $19.1 \mathrm{~cm}$. The $20-\mathrm{cm}$ DBH class was chosen over a smaller sawlog threshold $(15.1 \mathrm{~cm})$ because mean DBH was already $>15 \mathrm{~cm}$ prior to thinning (Table 2). Thus GSV provides a better evaluation of the production potential of large sawlogs (MRN 2003). Cumulative gross merchantable volume (CGMV) was calculated as the sum of harvested GMV and GMV 
15 years after harvest. Mortality was expressed as the percentage of postharvest density.

\section{Regeneration dynamics}

In each replicate, regeneration was measured on four $4-\mathrm{m}^{2}$ sub-plots located $8-\mathrm{m}$ from the centre of the $2500 \mathrm{~m}^{2}$ area in each cardinal direction. Regeneration was not determined prior to thinning but postharvest measurements took place shortly after harvest, as well as at 5,10 , and 15 years postharvest. Seedling density and stocking were determined by species and height classes: 1-5, 6-30, 31-60, $61-100, \quad 101-200, \quad 201-300$, and $>300 \mathrm{~cm}$. Saplings $(>1.0 \mathrm{~cm} \mathrm{DBH})$ were also measured by species and diameter class $(2,4,6$, and $8 \mathrm{~cm})$ in a $100 \mathrm{~m}^{2}$ circular plot at the centre of the $400 \mathrm{~m}^{2}$ plot. The term 'seedling' differentiates small regeneration from saplings, and does not imply stems resulting from seed. Sapling density (number of stems $\mathrm{ha}^{-1}$ ), seedling density, and seedling stocking ( $\%$ of sub-plots containing at least one living stem) were used to describe regeneration development.

\section{Statistical analyses}

\section{Growth and yield}

We tested the hypotheses using values calculated at the replicate level $(n=12 \times 4$ years $=48)$ to avoid inflating the number of degrees of freedom of the error term. The following linear mixed-effects model for repeated measurements was used (Gauthier and Tremblay 2018):

$Y_{i j k}=\mu+B_{i}+T_{j}+(B \times T)_{i j}+Y_{k}+(T \times Y)_{j k}+C_{i j k}+\varepsilon_{i j k}$

where $Y_{i j k}$ is the dependent variable, $\mu$ the overall mean of all treatments combined, $B_{i}$ the random effect of block $i$ $\left(i=1,2,3 ; B_{i} \sim N\left(0, \sigma_{B}^{2}\right)\right), T_{j}$ the fixed effect of thinning treatment $j$ ( $j=$ Control, CT27, CT32, CT47); $(B \times T)_{i j}$ is the random effect of the interaction between block $i$ and treatment $j\left[(B \times T)_{i j} \sim N\left(0, \sigma_{B * T}^{2}\right)\right], Y_{k}$ the fixed effect of year $k(k=1,5,10,15),(T \times Y)_{j k}$ the fixed effect of the interaction between treatment $j$ and year $k, C_{i j k}$ corresponds to the preharvest value as a covariate, and $\varepsilon_{i j k}$ is the experimental error.

$\boldsymbol{\varepsilon}_{i j}^{\prime}=\left[\begin{array}{llll}\varepsilon_{i j 1} & \varepsilon_{i j 5} & \varepsilon_{i j 10} & \varepsilon_{i j 15}\end{array}\right]$

$\boldsymbol{\varepsilon}_{i j}^{\prime}$ is the $4 \times 1$ vectors of error corresponding to the repeated measures of treatment $j$ in block $i$ over time, where $\boldsymbol{\varepsilon}_{i j} \sim \operatorname{iidN}(0, \boldsymbol{\Sigma})$ and $\boldsymbol{\Sigma}$ corresponds to the selected variance-covariance matrix used to account for the correlation between measurements done on the same replicate over time. This matrix was chosen to maximize the likelihood value of the model while using as few parameters as possible. For all analyses, the autoregressive covariance structure AR (1) was retained. All fixed interactions involving the covariate were tested but removed if not significant $(p<0.05)$.

Dependent variables were: DBH and GMV of surviving trees, i.e., those that were alive before thinning and for the entire measurement period, GMV, GSV, CGMV, and mortality. Descriptive statistics were used to characterize ingrowth of merchantable trees since it was low throughout the measurement period. Because CGMV is only measured once, it was analyzed without repeated measures. Homogeneity of variance and normality were verified for all analyses using residual plots. Data met normality and homogeneity of variance postulates, and transformations were unnecessary.

Multiple comparisons of fixed effects were carried out using least square means and least square means estimate for interactions. For significant effects involving $Y_{k}$, we tested for linear or quadratic fits over the 15 years. For all multiple comparisons, $p$ values were adjusted to account for multiplicity of tests using a simulation-based approach (Westfall et al. 2011). Significant differences were reported when $p<0.05$. All analyses were carried out with SAS software version 9.4 (SAS Institute Inc., Cary, NC).

\section{Regeneration}

Statistical analyses of regeneration were made using the same structure as growth and yield data but without covariates due to a lack of preharvest data. Analyzed variables included sapling density (all diameter classes combined), regeneration density (all height classes combined), and regeneration stocking (all height classes combined). Descriptive statistics characterized the regenerating cohort and helped to explain treatment effects (Gauthier et al. 2015). Squared root transformation was used on both density variables to meet homogeneity of variance and normality assumptions.

\section{Results}

\section{Growth and yield}

Mean DBH increased linearly with thinning intensity $(\mathrm{T} \times \mathrm{Y}$, Table 3, Fig. 2a). Compared to the unthinned control, only CT47 had a higher mean DBH for each measurement period. The difference between CT47 and the control was $2.9 \mathrm{~cm}$ immediately postharvest and reached $4.9 \mathrm{~cm}$ after 15 years. Mean GMV tree ${ }^{-1}$ increased linearly with thinning intensity $(\mathrm{T} \times \mathrm{Y}$, Table 3 , Fig. 2b). It 
was higher in CT47 $\left(0.407 \mathrm{~m}^{3}\right.$ tree $\left.{ }^{-1}\right)$ than in the control $\left(0.268 \mathrm{~m}^{3}\right.$ tree $\left.^{-1}\right) 10$ and 15 years after harvest. The difference in mean DBH $\left(0.139 \mathrm{~m}^{3}\right.$ tree $\left.^{-1}\right)$ represented a $52 \%$ increase over the control. Covariate effects were found for both DBH and GMV tree ${ }^{-1}$ (Table 3). Postharvest DBH and GMV tree ${ }^{-1}$ increased with increases in their corresponding preharvest values.

Stand GMV and GSV showed quadratic fits over time (Y, Table 3, Fig. 3a, b). The thinning effect (T, Table 3) in GMV showed higher values for CT27 compared to CT47 ( $p=0.048$, Fig. 3a). There were no significant differences for GSV among thinning treatments (Fig. 3b). The quadratic time effect (Y, Table 3) suggests that GSV reached its upper limit during the monitoring period (Fig. 3b). The thinning effect ( $\mathrm{T}$, Table 3) in CGMV 15 years after treatment indicated that mean CGMV was significantly higher in CT27 compared to the unthinned control ( $p=0.041$, Fig. $3 c$ ). In terms of species composition, jack pine still dominated merchantable BA with a mean of $91 \%$ 15 years after harvest.

Mortality increased over time in all treatments $(\mathrm{Y}$, Table 3), from $0 \%$ immediately after thinning to $31 \%$ after 15 years (Fig. 3d). Windthrow accounted for $25 \%$ of all mortality. About $60 \%$ of dead trees had a smaller diameter than the mean DBH of live trees, which still left a sizeable amount of mortality (40\%) in larger diameter classes. Jack pine was $92 \%$ of all mortality, with the residual evenly distributed among white birch, trembling aspen, and black spruce.

Ingrowth of merchantable trees over the 15-year period was low $\left(<100\right.$ stems ha $\left.^{-1}\right)$ and similar among treatments, ranging from 0.6 to $0.9 \mathrm{~m}^{2}$ ha $^{-1}$. Black spruce was $56 \%$ of merchantable BA ingrowth, followed by white birch with $21 \%$. Trembling aspen (12\%) and jack pine (11\%) accounted for the remaining ingrowth.

\section{Regeneration}

There were no differences in sapling density among treatments. It increased linearly over time from 350 stems ha $^{-1}$ after thinning to 1200 stems ha $^{-1}$ after 15 years (Y, Table 3, Fig. 4a). Saplings were mainly white birch (62\%) and black spruce (23\%) immediately after thinning, and the increase that occurred afterward was largely new saplings of white birch and black spruce in the 2-cm class. However, 15 years postharvest, white birch was still the most abundant species $(45 \%)$ but the proportion of black spruce almost doubled to $41 \%$. Jack pine sapling density was $5 \%$ regardless of time after thinning.

Seedling density also increased over time to 4700 stems $\mathrm{ha}^{-1}$ in year $15(\mathrm{Y}$, Table 3 ) but did not vary among treatments (Fig. 4b). During the same period, the proportion of black spruce increased from 28 to $72 \%$ of total seedling density while the proportion of jack pine decreased from 63 to $3 \%$. Descriptive statistics indicate that the increase in black spruce was mainly in the 6-30 and $31-60 \mathrm{~cm}$ height classes. For all species combined, seedlings were distributed among all height classes 15 years postharvest, with a minimum of $400 \mathrm{stems} \mathrm{ha}^{-1}$ in the $101-200 \mathrm{~cm}$ class and a maximum of $1800 \mathrm{stems} \mathrm{ha}^{-1}$ in the $31-60 \mathrm{~cm}$ class.

A $\mathrm{T} \times \mathrm{Y}$ interaction was found in seedling stocking (Table 3, Fig. 4c) but none of the multiple comparisons tested were significant at $p<0.05$. Stocking was similar amongst treatments after 15 years with a mean of $38 \%$. For all height classes and species combined, black spruce stocking was $23 \%$, trembling aspen $10 \%$, white birch $6 \%$, and jack pine $4 \%$.

\section{Discussion}

\section{Growth and yield}

Our findings, in terms of mean DBH and GMV tree ${ }^{-1}$, corroborate our first hypothesis as well as findings from other studies on jack pine after CT in North America (Bella and De Franceschi 1974; Krause et al. 2011). Krause et al. (2011) reported a mean radial growth difference of $43 \%$ at $0.2 \mathrm{~m}$ in height for postharvest years 3 and 4 compared to the 5 years prior to treatment in 10 commercially thinned jack pine stands in Québec. Bella and De Franceschi (1974) also obtained better diameter and volume growth in a denser jack pine stand on a less fertile site 15 years after treatment. Among DBH classes of $12-18 \mathrm{~cm}$, differences varied from 25 to $69 \%$ in DBH and $20 \%$ in mean GMV tree $^{-1}$ for heavy thinning from below (35\% BA removal).

Preharvest estimates of live crown ratio $(\leq 50 \%)$ and slenderness of codominant trees $(>80 \%)$ suggests that their ability to add radial growth in response to thinning was limited and that treatment was risky in terms of windthrow (Ruel 1995; Pelletier and Pitt 2008). For CT32, more large trees were harvested. This resulted in an immediate difference of only $1.4 \mathrm{~cm}$ in mean DBH. Therefore, the treatment could be classified more as a crown thinning rather than a thinning from below. This has likely resulted in leaving less vigorous trees which reduced long-term growth responses.

Increases in stem volume growth of jack pine after thinning are associated with increases in growth efficiency and foliage biomass around midcrown, likely from greater light availability (Goudiaby et al. 2011, 2012). More carbohydrates are thus allocated to diameter growth which has a lower priority compared to height growth (Lanner 1985). As for covariate effects, they highlight the need to consider preharvest diameter. For example, the replicate with the 
Table 3 Analyses of variance of response variables according to preharvest conditions (covariate), three commercial thinning intensities and an unthinned control, and measurement year (postharvest, $5,10,15$ years after harvest). To simplify presentation, random effects and multiple comparisons were not shown

\begin{tabular}{|c|c|c|c|c|c|c|}
\hline Objective & Variable & Fixed effect & ndf & ddf & $F$-value & $p$ value \\
\hline \multirow[t]{29}{*}{ Growth and yield } & $\mathrm{DBH}$ & $\mathrm{C}$ & 1 & 6.9 & 20.3 & 0.003 \\
\hline & \multirow[t]{5}{*}{ Tree $^{-1}$} & $\mathrm{~T}$ & 3 & 7.0 & 7.4 & 0.001 \\
\hline & & $\mathrm{Y}$ & 3 & 23.9 & 176.4 & $<0.001$ \\
\hline & & $\mathrm{T} \times \mathrm{Y}$ & 9 & 23.9 & 4.0 & 0.003 \\
\hline & & Linear $^{\mathrm{a}}$ & 1 & 25.5 & 15.9 & $<0.001$ \\
\hline & & Quadratic $^{\mathrm{a}}$ & 1 & 23.2 & -0.24 & 1.000 \\
\hline & GMV & $\mathrm{C}$ & 1 & 7.0 & 19.9 & 0.003 \\
\hline & \multirow[t]{5}{*}{ Tree $^{-1}$} & $\mathrm{~T}$ & 3 & 7.1 & 2.7 & 0.125 \\
\hline & & $\mathrm{Y}$ & 3 & 24.0 & 205.3 & $<0.001$ \\
\hline & & $\mathrm{T} \times \mathrm{Y}$ & 9 & 24.0 & 6.2 & $<0.001$ \\
\hline & & Linear $^{\mathrm{a}}$ & 1 & 25.1 & 17.7 & $<0.001$ \\
\hline & & Quadratic $^{\mathrm{a}}$ & 1 & 23.4 & 1.4 & $\geq 0.891$ \\
\hline & \multirow[t]{5}{*}{ GMV } & $\mathrm{T}$ & 3 & 5.9 & 5.2 & 0.042 \\
\hline & & $\mathrm{Y}$ & 3 & 22.3 & 5.6 & 0.005 \\
\hline & & Y linear & 1 & 29.8 & -1.7 & 0.162 \\
\hline & & Y quadratic & 1 & 20.5 & -3.5 & 0.005 \\
\hline & & $\mathrm{T} \times \mathrm{Y}$ & 9 & 22.3 & 1.0 & 0.463 \\
\hline & \multirow[t]{6}{*}{ GSV } & $\mathrm{C}$ & 1 & 6.7 & 5.8 & 0.049 \\
\hline & & $\mathrm{T}$ & 3 & 6.7 & 2.2 & 0.185 \\
\hline & & $\mathrm{Y}$ & 3 & 21.4 & 5.0 & 0.009 \\
\hline & & Y linear & 1 & 29.8 & 1.2 & 0.438 \\
\hline & & Y quadratic & 1 & 21.5 & -3.5 & 0.005 \\
\hline & & $\mathrm{T} \times \mathrm{Y}$ & 9 & 21.4 & 0.5 & 0.869 \\
\hline & CGMV & $\mathrm{T}$ & 3 & 6.0 & 5.0 & 0.046 \\
\hline & \multirow[t]{5}{*}{ Mortality } & $\mathrm{T}$ & 3 & 3.9 & 2.0 & 0.255 \\
\hline & & $\mathrm{Y}$ & 3 & 22.0 & 18.5 & $<0.001$ \\
\hline & & Y linear & 1 & 15.3 & 6.8 & $<0.001$ \\
\hline & & Y quadratic & 1 & 11.1 & 2.9 & 0.026 \\
\hline & & $\mathrm{T} \times \mathrm{Y}$ & 9 & 12.8 & 2.1 & 0.105 \\
\hline \multirow[t]{15}{*}{ Regeneration } & Sapling & $\mathrm{T}$ & 3 & 6.0 & 0.4 & 0.788 \\
\hline & \multirow[t]{4}{*}{ Density } & $\mathrm{Y}$ & 3 & 24.0 & 6.4 & 0.003 \\
\hline & & Y linear & 1 & 24.0 & 4.3 & $<0.001$ \\
\hline & & Y quadratic & 1 & 24.0 & 0.8 & 0.678 \\
\hline & & $\mathrm{T} \times \mathrm{Y}$ & 9 & 24.0 & 0.7 & 0.729 \\
\hline & Seedling & $\mathrm{T}$ & 3 & 6.0 & 1.3 & 0.360 \\
\hline & \multirow[t]{4}{*}{ Density } & $\mathrm{Y}$ & 3 & 13.4 & 4.0 & 0.030 \\
\hline & & Y linear & 1 & 7.0 & 2.5 & 0.054 \\
\hline & & Y quadratic & 1 & 23.7 & -1.2 & 0.434 \\
\hline & & $\mathrm{T} \times \mathrm{Y}$ & 9 & 13.4 & 1.0 & 0.502 \\
\hline & Seedling & $\mathrm{T}$ & 3 & 5.9 & 0.1 & 0.958 \\
\hline & \multirow[t]{4}{*}{ Stocking } & $\mathrm{Y}$ & 3 & 15.5 & 0.2 & 0.924 \\
\hline & & $\mathrm{T} \times \mathrm{Y}$ & 9 & 15.5 & 2.9 & 0.032 \\
\hline & & Linear $^{\mathrm{a}}$ & 1 & 9.7 & 1.4 & $\geq 0.921$ \\
\hline & & Quadratic $^{\mathrm{a}}$ & 1 & 23.8 & -3.3 & $\geq 0.081$ \\
\hline
\end{tabular}

Abbreviations are defined in Table 1. Significant effects $(p<0.05)$ indicated in bold

${ }^{\mathrm{a}}$ Values of linear and quadratic effects of the $\mathrm{T} \times \mathrm{Y}$ interaction are shown for the treatment with the lowest $p$ value only 

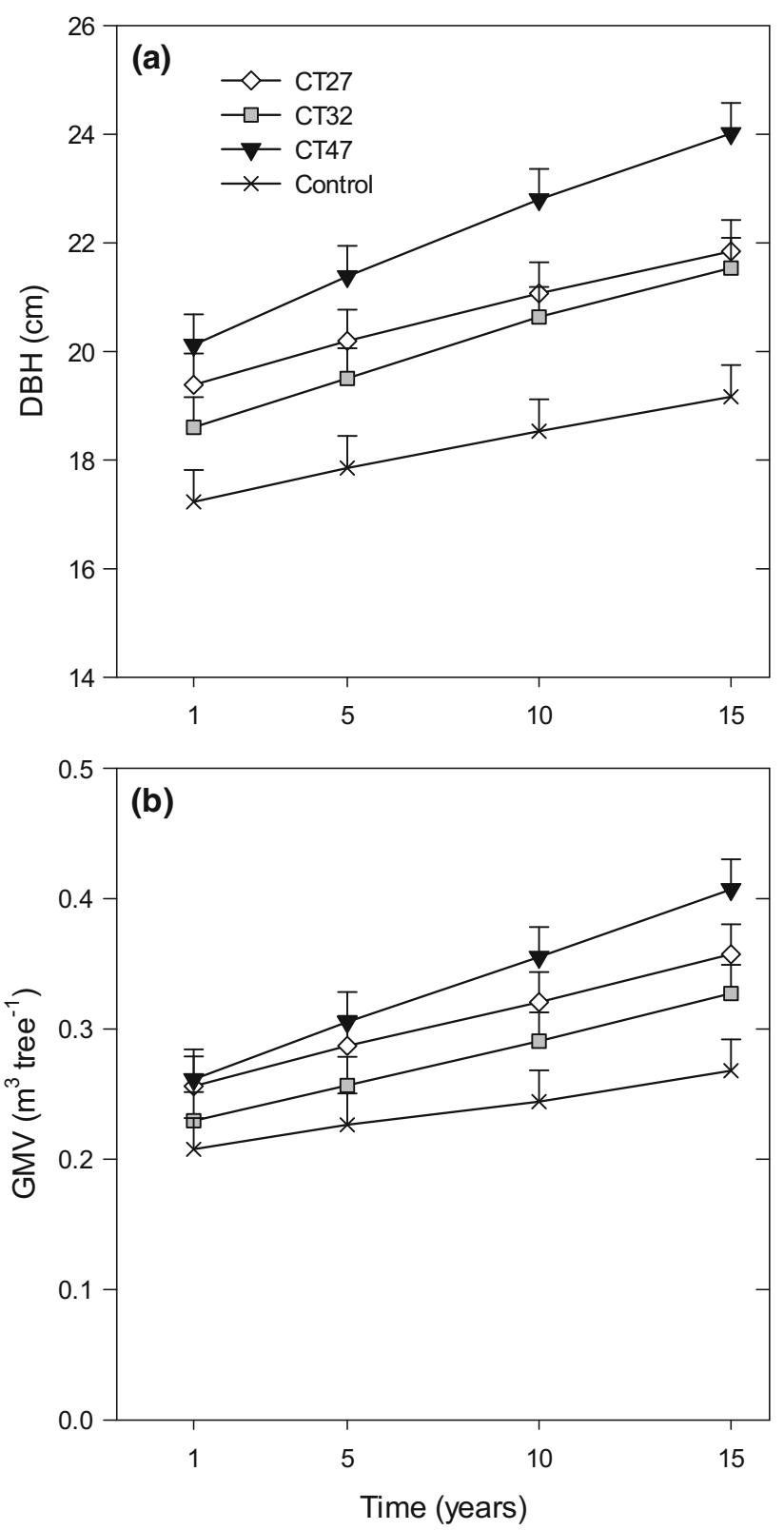

Fig. 2 Mean a DBH and b GMV per tree after three commercial thinning intensities and an unthinned control. Measurement year is defined as postharvest (1), 5, 10, and 15 years after thinning. Values $(+1 \mathrm{SE})$ are those obtained from statistical analyses at the mean value of the covariate. Abbreviations are defined in Table 1

highest preharvest value had a mean diameter $6 \mathrm{~cm}$ larger than the replicate with the smallest preharvest value 15 years after treatment.

In terms of stand GMV, GSV, and CGMV, results did not support our second hypothesis because the $27 \%$ BA removal maximized volume production. Indeed, standlevel GMV was higher in CT27 compared to CT47 after 15 years. Moreover, CGMV in CT27 was higher than in the unthinned control. Maintenance of acceptable growing stock in CT27 could provide other ecosystem functions, such as biodiversity or wildlife habitat, by delaying senescence (Soucy et al. 2012). Further monitoring will help determine the duration of this potential benefit. This can be of great interest even for short-lived, shade-intolerant pioneer species like jack pine in a sustainable forest management context.

Published findings on CT have found negative (Tremblay and Laflèche 2013) or neutral (Pelletier and Pitt 2008) stand-level responses depending upon stand conditions, site quality, thinning intensity, and timing of first entry. Pelletier and Pitt (2008) did not find any stand-level differences in volume associated with late-entry $\mathrm{CT}$ in spruce plantations compared to unthinned plantations. Using 5 -year postharvest data from a network of sample plots established in jack pine stands throughout Québec, Tremblay and Laflèche (2013) found that late thinning entries actually led to lower GMV increment, GMV, GSV, and CGMV in thinned plots compared to those found in unthinned plots. Contrasting results from the literature compared to our findings may be explained, at least in part, by the relatively high mortality found in our study. For stands growing on a site with a site index of $18 \mathrm{~m}$, jack pine enters senescence between the age 64-76 (MRNFPQ 2004). Considering that the site index in our stand is $21 \mathrm{~m}$, senescence has likely begun during the last 5 -year period. This is corroborated by the $40 \%$ of mortality that occurred in larger diameter classes, even in the unthinned control (34\%). Although intraspecific competition can be substantial in jack pine stands (Béland et al. 2003b), the mortality that results from competition during the selfthinning process mainly occurs in smaller size classes (Kenkel 1988; Kenkel et al. 1997). Furthermore, interspecific competition is unlikely to have played a major role in our study, given the low abundance of other species. Windthrow also contributed to high mortality. This was expected because of the high slenderness coefficient measured on dominant and codominant trees. It also implies that intermediate and suppressed trees probably had an even higher slenderness coefficient, and 55\% of windthrow mortality occurred in smaller trees. Other possible explanations for high mortality include natural root grafting which can influence the growth response of jack pine trees to CT (Tarroux et al. 2010).

\section{Regeneration}

The results show that thinning did not have a notable impact on the abundance of regeneration for the first 15 years after treatment. In a similar study carried out in spruce-fir stands, Olson et al. (2014) found that small $(11-60 \mathrm{~cm}$ height) coniferous and hardwood regeneration were much more abundant in thinned stands compared to unthinned stands 10 years postharvest. The authors also reported 
Fig. 3 Mean a GMV, b GSV, c CGMV, and d mortality (\% of postharvest density) after three intensities of commercial thinning and an unthinned control. Measurement year is defined as postharvest (1), and 5,10 , and 15 years after thinning. Means (+ $1 \mathrm{SE})$ are those obtained from statistical analyses. For part c, means with different letters are significantly different at $p<0.05$.

Abbreviations are defined in Table 1
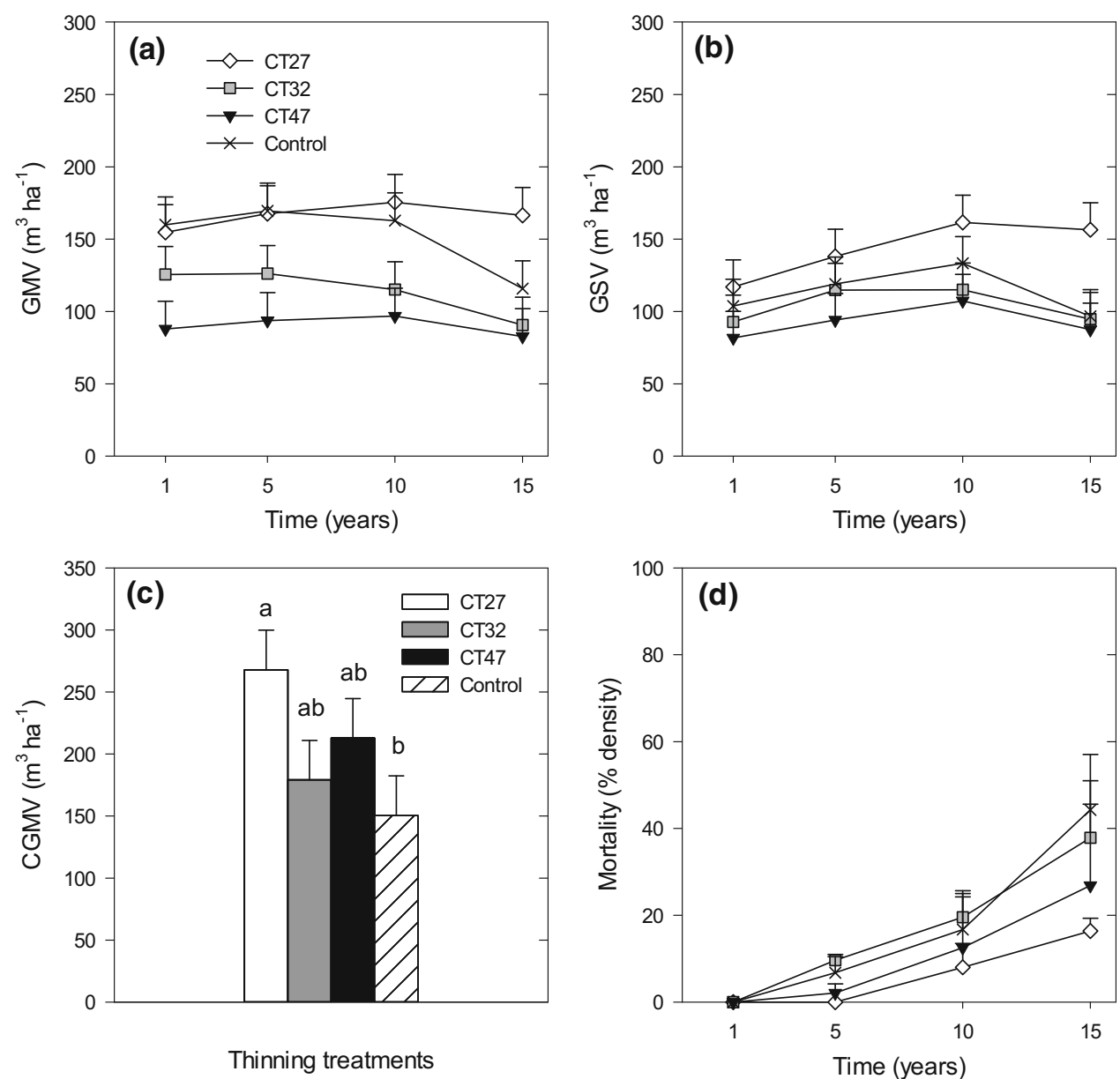

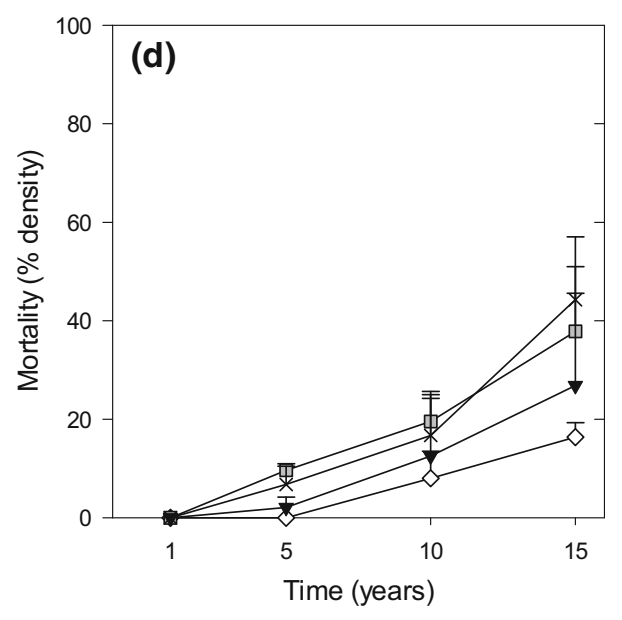

similar coniferous regeneration density between thinned and unthinned stands for medium $(61-140 \mathrm{~cm})$ and large $(\geq 141 \mathrm{~cm})$ size classes. Findings from the literature are inconsistent because tree regeneration is stochastic (Bataineh et al. 2013) and stand age varies at the time of the first thinning. Regeneration after thinning can vary greatly depending upon stand and site conditions, microsite heterogeneity, and seedling clustering (Ares et al. 2010). Moreover, thinning was not carried out to establish a regeneration cohort and no particular emphasis was placed on creating favorable microsite conditions. We hypothesize that density increases in thinned replicates were related to openings created by harvesting while mortality in the unthinned control promoted regeneration in a similar fashion, thus mitigating potential differences among treatments.

Regeneration data revealed that species other than jack pine accounted for most of the increases in the three response variables. First, the gradual increase in sapling density was attributed to white birch and black spruce in the 2-cm diameter class. This is logical, considering that white birch was the most abundant sapling species (45\%), followed closely by black spruce with $41 \%$. Jack pine saplings were scarce, representing $<5 \%$ of total sapling density regardless of time after thinning. Second, the increase in regeneration density was caused by black spruce in the 6-30, 31-60, and 61-100 cm height classes. Third, for all height classes and treatments combined, jack pine stocking was $25 \%$ immediately after harvest, $0 \%$ at year 5 , and only $4 \%$ at year 15 .

Combining these results with ingrowth of merchantable stems indicates that a shift in species composition occurred, from jack pine-dominated in the overstory to a mixture of black spruce, white birch, and trembling aspen in the understory. All three species have competitive advantages over jack pine: black spruce requires few seed trees to constitute a viable seed bank and promote its shade-tolerant regeneration, white birch can generate abundant seed during a good crop year, and trembling aspen can reproduce sexually by seed or asexually by stump sprouting. In contrast, jack pine requires fire to open up seed cones, seedlings cannot tolerate understory shade, and asexual reproduction is limited. Additionally, visual observation of the study site suggests that mountain alder (Alnus viridis (Chaix) DC. ssp. crispa (Aiton) Turrill) and Labrador tea (Ledum groenlandicum Oeder) are found 

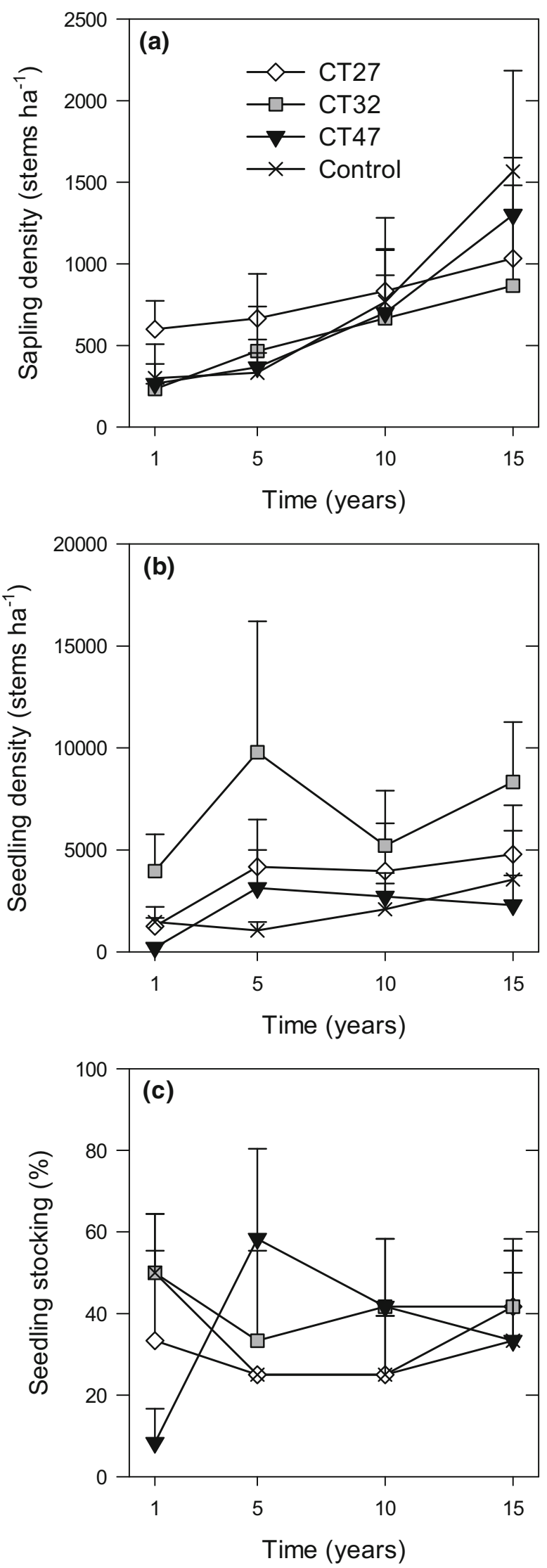

Fig. 4 Regeneration a sapling density, b seedling density, and c seedling stocking after three intensities of commercial thinning and an unthinned control. Measurement year is defined as postharvest (1), and 5, 10, and 15 years after thinning. Means and associated variation (+ $1 \mathrm{SE})$ are those obtained from statistical analyses. Abbreviations are defined in Table 1

throughout the understory. Both species can form dense thickets that reduce conifer seedling establishment and growth after harvesting. Thus, jack pine will have difficulty regenerating in this stand. The transition from a pure jack pine stand into a mixed-species stand with a jack pine component has been shown after clearcutting by Béland et al. (2010) in Québec. This transition also occurs naturally in the absence of fire over the long-term ( $\sim 150$ years, Smirnova et al. 2008). Our findings suggest CT also maintains the shift in species composition on productive sites.

If regenerating jack pine is an objective after final overstory removal, additional efforts will be needed to reestablish this species in the regenerating cohort. Studies have found that this could include combinations of treatments such as cut-to-length clearcutting with off-site delimbing, scarification, and planting (Man et al. 2009, 2011; Béland et al. 2010). Herbicide application could also be effective in releasing planted jack pine from competition (Man et al. 2009, 2011), but it cannot be used in certain jurisdictions like Québec. Enrichment planting of jack pine after partial cutting (50\% BA removal) was studied in a mixed-species stand of trembling aspen, white birch, black spruce, jack pine, and balsam fir (Man et al. 2009). Findings 14 years after harvest showed that planted jack pine had low survival $(\sim 25 \%)$. Moreover, planted seedlings had only half the height $(\sim 150 \mathrm{~cm})$ and rootcollar diameter $(\sim 2 \mathrm{~cm})$ as those found in the clearcut, resulting from vigorous growth of understory shrubs. Hence, planting may be more effective after final overstory removal.

\section{Conclusions}

The long-term monitoring period of this study helped address two novel aspects in commercially thinned jack pine stands: (1) the early stages of senescence; and, (2) regeneration dynamics. In terms of growth and yield, we conclude that the highest thinning intensity produced larger trees on average, while the lowest thinning intensity maximized volume production per hectare. The maintenance of acceptable growing stock in CT27 could help maintain other important ecosystem functions, such as wildlife habitat or biodiversity, by delaying senescence. 
Regeneration data showed that sapling and seedling density increased over time in all treatments. After 15 years, species composition in the understory was a mixture of black spruce, white birch, and trembling aspen. Hence, additional regeneration efforts will be necessary if jack pine is to be favored in the understory regardless of thinning intensity due to the shift in species composition.

Acknowledgements We thank all of the technicians for data collection and David Pothier for initiating and establishing the experiment.

Open Access This article is distributed under the terms of the Creative Commons Attribution 4.0 International License (http://crea tivecommons.org/licenses/by/4.0/), which permits unrestricted use, distribution, and reproduction in any medium, provided you give appropriate credit to the original author(s) and the source, provide a link to the Creative Commons license, and indicate if changes were made.

\section{References}

Ares A, Neill AR, Puettmann KJ (2010) Understory abundance, species diversity and functional attribute response to thinning in coniferous stands. For Ecol Manag 260:1104-1113

Arseneault D, Sirois L (2004) The millennial dynamics of a boreal forest stand from buried trees. J Ecol 92:490-504

Barbour RJ, Fayle DCF, Chauret G, Cook J, Karsh MB, Ran S (1994) Breast-height relative density and radial growth in mature jack pine (Pinus banksiana) for 38 years after thinning. Can J For Res 24:2439-2447

Bataineh MM, Kenefic LS, Weiskittel AR, Wagner RG, Bissette JC (2013) Influence of partial harvesting and site factors on the abundance and composition of natural regeneration in the Acadian Forest of Maine, USA. For Ecol Manag 306:96-106

Béland M, Bergeron Y, Zarnovican R (2003a) Harvest treatment, scarification and competing vegetation affect jack pine establishment on three soil types of boreal mixed wood of northwestern Quebec. For Ecol Manag 174:477-493

Béland M, Lussier J-M, Bergeron Y, Longpré M-H, Béland M (2003b) Structure, spatial distribution and competition in mixed jack pine (Pinus banksiana) stands on clay soils of eastern Canada. Ann For Sci 60:609-617

Béland M, Camels S, Bergeron Y (2010) Natural regeneration of jack pine on clay soils following harvesting and site preparation: seventh-year results. For Chron 86:423-433

Bell FW, Dacosta J, Penner M, Morneault A, Stinson A, Towill B, Luckai NJ, Winters J (2011) Longer-term volume trade-offs in spruce and jack pine plantations following various conifer release treatments. For Chron 87:235-250

Bella IE, De Franceschi JP (1974) Commercial thinning improves growth of Jack pine. Canadian Forest Service, Department of Environment, North Forest Research Centre, Inf Rep NOR-X112

Bergeron Y, Dubuc D (1989) Succession in the southern part of the Canadian boreal forest. Vegetatio 79:51-63

Chun YM, Choi YD (2012) Structure, species composition, and soil characteristics in a chronosequence of jack pine (Pinus banksiana Lamb.) stands on the southern shore of Lake Michigan. Am Midl Nat 168:408-426

Drössler L, Nilsson U, Lundqvist L (2014) Simulated transformation of even-aged Norway spruce stands to multi-layered forests: an experiment to explore the potential of tree size differentiation. Forestry 87:239-248

Fortin M, DeBlois J, Bernier S, Blais G (2007) Mise au point d'un tarif de cubage général pour les forêts québécoises: une approche pour mieux évaluer l'incertitude associée aux prévisions. For Chron 83:754-765

Fortin M, Bernier S, Saucier J-P, Labbé F (2009) Une relation hauteur-diamètre tenant compte de l'influence de la station et du climat pour 20 espèces commerciales du Québec. [A heightdiameter relationship that takes into account the influence of site conditions and climate for 20 commercial species of Québec]. Government of Québec, Ministry of Natural Resources, Forest Research Branch, General Technical Report 153

Friedman SK, Reich PB (2005) Regional legacies of logging: departure from presettlement forest conditions in northern Minnesota. Ecol Appl 15:726-744

Gauthier M-M, Tremblay S (2018) Precommercial thinning as a silvicultural option for treating very dense conifer stands. Scand J For Res 33:446-454

Gauthier M-M, Barrette M, Tremblay S (2015) Commercial thinning to meet wood production objectives and develop structural heterogeneity: a case study in the spruce-fir forest, Quebec, Canada. Forests 6:510-532

Goudiaby V, Brais S, Grenier Y, Berninger F (2011) Thinning effects on jack pine and black spruce photosynthesis in eastern boreal forests of Canada. Silva Fenn 45:595-609

Goudiaby V, Brais S, Berninger F, Schneider R (2012) Vertical patterns in specific volume increment along stems of dominant jack pine (Pinus banksiana) and black spruce (Picea mariana) after thinning. Can J For Res 42:733-748

Greene DF, Zasada JC, Sirois L, Kneeshaw D, Morin H, Charron I, Simard M-J (1999) A review of the regeneration dynamics of North American boreal forest tree species. Can J For Res 29:824-839

Kenkel NC (1988) Pattern of self-thinning in jack pine: testing the random mortality hypothesis. Ecology 69:1017-1024

Kenkel NC, Hendrie MLI, Bella IE (1997) A long-term study of Pinus banksiana population dynamics. J Veg Sci 8:241-254

Krause C, Laplante S, Plourde P-Y (2011) Transversal tracheid dimension in thinned black spruce and jack pine stands in the boreal forest. Scand J For Res 26:477-487

Lanner RM (1985) On the insensitivity of height growth to spacing. For Ecol Manag 13:143-148

Lichter J (1998) Plant succession and forest development on coastal Lake Michigan sand dunes. Ecol Monogr 68:487-510

Man R, Rice JA, MacDonald GB (2009) Long-term response of planted conifers, natural regeneration, and vegetation to harvesting, scalping, and weeding on a boreal mixedwood site. For Ecol Manag 258:1225-1234

Man R, Rice JA, MacDonald GB (2011) Early effects of pre- and post-harvest herbicide application and partial cutting in regenerating aspen-jack pine mixtures in northeastern Ontario. Can J For Res 41:1082-1090

MRN (2003) [Ministère des Ressources Naturelles] Avis scientifique: Éclaircie commerciale pour le groupe de production prioritaire SEPM. [Scientific notice: Commercial thinning for the spruce, pine, fir, and larch production group]. Government of Québec, Québec

MRNFPQ (2004) [Ministère des Ressources naturelles, de la Faune et des Parcs du Québec] Détermination de l'âge approximatif d'entrée en sénescence des principaux peuplements forestiers à l'aide des placettes-échantillons temporaires. Suivi d'une analyse comparative. [Determination of the approximate age of entry into senescence of forest stands using temporary sample plotsfollow-up to a comparative analysis]. Government of Québec, Québec 
Olson MG, Meyer SR, Wagner RG, Seymour RS (2014) Commercial thinning stimulates natural regeneration in spruce-fir stands. Can J For Res 44:173-181

Pelletier G, Pitt DG (2008) Silvicultural responses of two spruce plantations to midrotation commercial thinning in New Brunswick. Can J For Res 38:851-867

Pothier D, Savard F (1998) Actualisation des tables de production pour les principales espèces forestières du Québec. [Updated production tables for Québec's main forest tree species]. Government of Québec, Québec

Ruel J-C (1995) Understanding windthrow: silvicultural implications. For Chron 71:434-445

Schneider R, Zhang ZY, Swift DE, Bégin J, Lussier J-M (2008) Predicting selected wood properties of jack pine following commercial thinning. Can J For Res 38:2030-2043

Sharma M, Zhang SY (2007) Stand density management diagram for jack pine stands in Eastern Canada. North J Appl For 24:22-29

Smirnova E, Bergeron Y, Brais S (2008) Influence of fire intensity on structure and composition of jack pine stands in the boreal forest of Quebec: live trees, understory vegetation and dead wood dynamics. For Ecol Manag 255:2916-2927

Soucy M, Lussier J-M, Lavoie L (2012) Long-term effects of thinning on growth and yield of an upland black spruce stand. Can J For Res 42:1669-1677

Sullivan TP, Sullivan DS (2016) Acceleration of old-growth structural attributes in lodgepole pine forest: tree growth and stand structure 25 years after thinning. For Ecol Manag 365:96-106
Tarroux E, DesRochers A, Krause C (2010) Effect of natural root grafting on growth response of jack pine (Pinus banksiana) after commercial thinning. For Ecol Manag 260:526-535

Tong QJ, Zhang SY (2005) Impact of initial spacing and precommercial thinning on jack pine tree growth and stem quality. For Chron 81:418-428

Tong QJ, Zhang SY, Thompson M (2005) Evaluation of growth response, stand value and financial return for pre-commercially thinned jack pine stands in northwestern Ontario. For Ecol Manag 209:225-235

Tremblay S, Laflèche V (2013) Résultats 5 ans après traitement dans les placettes du réseau de la mesure des effets réels de l'éclaircie commerciale en peuplements résineux. [Five year effects of commercial thinning in a plot network located in conifer stands]. Government of Québec, Ministry of Natural Resources, Forest Research Branch, General Technical Report 166

Waters I, Kembel SW, Gingras J-F, Gray JM (2004) Short-term effects of cut-to-length versus full-tree harvesting on conifer regeneration in jack pine, mixedwood, and black spruce forests in Manitoba. Can J For Res 34:1938-1945

Westfall PH, Tobias RD, Wolfinger RD (2011) Multiple comparisons and multiple tests using SAS, 2nd edn. SAS Institute, Cary, p 625

Zhang SY, Chauret G, Swift DE, Duchesne I (2006) Effects of precommercial thinning on tree growth and lumber quality in a jack pine stand in New Brunswick, Canada. Can J For Res 36:945-952 